\title{
ナトリウム $(\mathrm{N} \mathrm{a})$ 限流素子の自己復旧特性と 低圧配電回路応用における過電流協調
}

\author{
正員 和 田 勇 一 (菱電機) \\ 正員 浜 野 末 信 (茂雨機) \\ 正貝 森 貞 次 郎 (黄電機)
}

\begin{abstract}
Self-rehealing Characteristics of a Sodium Current Limiter and its Over Current Coordination for Low Voltage Distribution Systems
\end{abstract}

Yuuichi Mada, Member, Suenobu Hamano, Member, Teijirou Mori, Member (Mitsubishi Electric Corporation)

A sodium current limiter, which has been developed and applied for low voltage use, is not a current limiting fuse but a new type of reusable current limiting device which utilizes metallic sodium as a fusible element. The excellent current limiting performance and the quick self-rehealing properties of the sodium limiter allowed highly reliable electric power systems to be obtained economically and compactly.

In this paper we experimentally examine the rehealing properties of the sodium limiter after current limiting operation and discuss the over current coordination of the sodium limiter for a low voltage distribution system. The results are summarized below.

(1) The resistance of the sodium limiter, being between about one thousand and several thousand times its normal resistance $r_{0}$ at room temperature during a current limiting operation of short circuit fault currents, changes abruptly to 30 to 40 times $i$ ts $r_{0}$ value just after the disappearance of the fault current and falls steadily to $r_{0}$.

(2) The sodium limiter can recover current carrying capability for a over load current even immediately after a current limiting operation and maintain its capability for the following normal load current. The upper limit of the recovery of the sodium limiter is given by its over current against the time characteristics under the normal condition.

(3) The self-rehealing characteristics of the sodium limiter presented here give the ability to design a low voltage motor control center using the sodium limiter which maintains maximum service continuity up to high fault currents.

キーワード：遮断器, ヒューズ, 限流装置, 自己復旧型限流素子, ナトリウム限流素子

\section{1.まえがき}

電力回路における短絡保護方式の一つとして，限流遮断 と呼ばれる方式がある。これは回路に短絡事故が発生して 短絡電流が流れ始めたとき，なんらかの方法によってこの 電流を波高值に逢する前にある一定值以下に制限し遮断す る方式である。短絡事故における機器の熱的あるいは笔磁 カによる機械的な苛酷度は短絡電流睖淔の 2 乗に比例す るので，限流遮断は機器の損傷あるいは耐量の低隇が可能 になるという点で非常に好ましい保護方式である。
限流遮断を行なう機能素子としてもっともよく知られて いるものとして限流七ューズがある。しかし限流上ューズ は，限流遮断動作でエレメントが溶断すると再び電流を流 すことができないため，限流遮断動作後正常な状態に復旧 させるためには取り替えなければならないという欠点をも っている。この欠点をなくし，かつ限流機能を有する新し い素子としてアルカリ金属のナトリウム（N a ）をエレメ ントにもつ自己復旧型の限流素子が開発され，優れた限流 機能亡異常大電流除去後の高速再通電機能の二つの特幑を 併せ持つものとして実用化されている［1］［2］。 
本論文では，ナトリウムを用いた自己復旧型の限流素子 （以下N a 限流素子と称する）について，特徴ある機能で ある限流動作後の自己復旧特性と再通電特性を実験的に明 らかにするとともに，この二つの機能を最大限に生かした 応用例としてコントロールセンタの主回路限流装置に適用 する場合に， $\mathrm{N}$ a 限流素子の再通電性能と適用負荷の許容 再通電容量に関する過電流領域の協調について検討を行な $っ た[3]$ 。

\section{2. $\mathrm{N}$ a 限流素子とその適用}

$<2.1>\mathrm{N}$ a 限流美子の棈造と動作 図 1 は自己 復旧型 $\mathrm{N}$ a 限流素子の構造断面図で，本実験のために中間 電極と信号端子を設けている他は製品と同じである。基本 的には 2 つの電流端子とこれを接続する金属ナトリウム

( $\mathrm{N}$ a ）の電路，ならびにピストンと高压封入された不活 性ガスからなる加圧機構とから構成されている。N a の電 路は高い熱伝導率をもつ锠器円筒によって囲まれており， さらに磁器円筒には特殊絶縁物を介して金属外筒によるや きばめが施され高い内圧に耐えるようになっている。加圧 機構はN a に王力を加え素子が常時導通を保つようにする とともに，限流動作時に発生する内部の圧力上昇を和らげ る緩衝機棈の役目もしている。N a は定常電流通電中は子 一ズ状のやわらかい固体または液体の状態で低抵抗である が，短絡電流のような大電流が流れるとジュール発熱によ り急速に加熱されて気化し高温高圧力のプラズマ状態とな り高抵抗となる。このため短絡電流は一定值以下に抑制す なわち限流される。加圧機構と反対側の $\mathrm{N}$ a 電路の一部に ノッチと呼ぶ断面縮小部を設けており, 限流動作の際 $\mathrm{Na}$ の気化がノッ部から開始し磁器内筒内の電路すへてにわ たって生ずるようにしている。限流された電流が他の直列 スイッチで除去されると， $\mathrm{N}$ a は周囲の磁器円筒への効果 的な放熱とピストンによる圧縮力を受けてすみやかに液化 または固化し，低抵抗状態となって再通電の機能を回復す る。

<2. $2>$ 適用回路図 2 は $\mathrm{N}$ 限流素子を電動機 の開閉制御を行う低圧コントロールセンタの主回路に応用 する場合の単線回路図である。主回路部分はN a 限流素子 ( N C L ) と 2 3 サイクルの遅延開極動作 (Short Time Delay : S T D ) 要素をもつ主回路配線用遮断器 ( N F M ) とが直列に接続された構成となっており，主回路につつく 分岐回路部分は分岐回路配線用遮断器 ( $\mathrm{NF}_{1}$ 等) や電酸 開閉器 (M S 等) などの開閉制御機器を経て電動機目荷 （L，等）へ接続された構成となっている。

つぎにこの回路の動作を述へる。まず分岐回路のA点に おける短絡事故を考える。短絡電流の大きさがN F 1 の遮 断容量以下の場合には，N C Lは限流動作をしないかある いはわずかに動作するように設定されていて，N F、はほ 浊力で短絡電流を遮断する。短絡電流がN F 1 の遮断容 量を越える場合には， N F 1 は N C L の限流動作の助けを 受けつつ，自己の遮断容量以下に限流された短絡電流を短

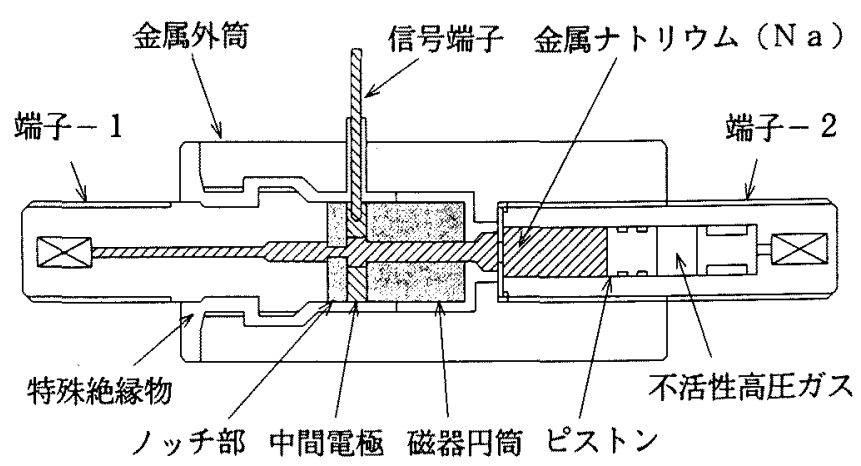

図 1. $\mathrm{N}$ a 限流素子の構造断面図

Fig. 1. Cross section of a sodium limiter.

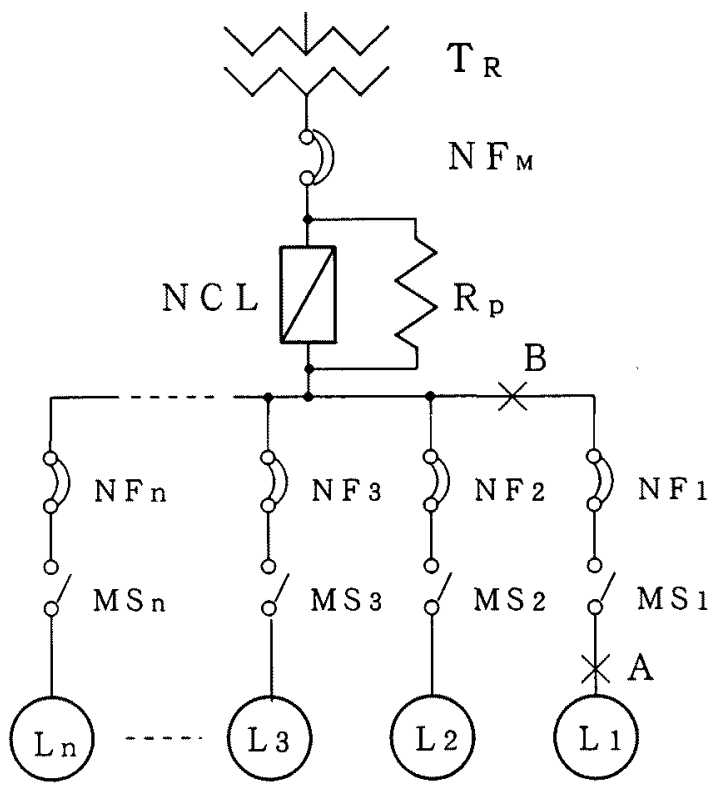

$\mathrm{T}_{\mathrm{R}}$ ：変王器 $\mathrm{NCL}: \mathrm{N}$ a限流素子 $\mathrm{Rp}$ ：亚列抵抗 NFM：主回路配線用遮断器 (Short Time Delay 付) $\mathrm{NF}_{1} \sim \mathrm{NFn}$ ：分岐回路配線用遮断器

$\mathrm{MS}_{1} \sim \mathrm{MSn}$ : 電磁開閉器 $\quad \mathrm{L}_{1} \sim \mathrm{Ln}_{\mathrm{n}}$ ：負荷

図 2. $\mathrm{N}$ a 限流素子を適用したコントロールセン 夕の回路図

Fig. 2. Skelton circuit of a control center utilizing a sodium limiter.

絡発生後約 $1 / 2$ サイクルと非常に高速に遮断する。この ような保護を後備保護あるいはカスケードバックアップと 呼ぶ。このとき，S T D 要素があるためN F M は動作せず, NF、により事故の分岐回路（L，回路）だけが選択的に除 去される。したがって他の健全な分岐回路負荷（L $\mathrm{L}_{2} \sim$ L n ）には無停電で電力が供給される。すなわち事故範囲 の局所化が行われ、これを選択保護と呼ぶ。つぎに母線 のB点における短絡事故を考える。この場合ＮＣＬは， $\mathrm{NF}_{\mathrm{M}}$ が遮断するまでの $2 \sim 3$ サイクルの間, 短絡電流を N F ${ }_{M}$ の遮断容量以下に限流して $\mathrm{N} \mathrm{F}_{\mathrm{M}}$ の遮断を助けるとと もに，下位のみならず上位の直列機器の損傷をも防ぐこと ができる。なお同図に示すように，実際の回路では限流動 
作時における異常笪圧の抑制やN C L の苛酷度の低減のた め，NCLに並列に抵抗（R p ）が接続されている。

以上述へたように，NCＬをかかる回路構成へ適用した 場合には，これまで難しいとされていたカスケード限流遮 断と選択限流遮断の両立が最大短絡電流まで成立するので， 短絡電流が系統に及ぼす電気的摄乱の抑制，熱的および電 磁機械的苛酷度の低減，ならびに健全な負荷への䉓力供給 信頼性の大棏な向上が可能となる。

\section{3. $\mathrm{N}$ a 限流素子の復旧特性}

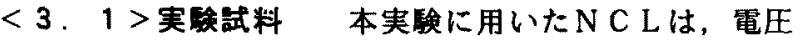
が 3 相 $460 \mathrm{~V}$, 電流が $800 \mathrm{~A}$, 限流可能な短絡電流が $170 \mathrm{kA}$ A定格を有している。素子外形は，長さ 287 $\mathrm{mm}$, 最大外径 $60 \mathrm{~mm}$ であり, $\mathrm{N}$ a 電路の形状は, ノッ 千部分が直径 $3.5 \mathrm{~mm}$, 長さ $7 \mathrm{~mm}$, 非ノッチ部と呼ぶ ノッチ部以外の部分が直径 $6 \mathrm{~m} \mathrm{~m}$, 長さ $30 \mathrm{~mm}$ である。 また素子の室温 $\left(25^{\circ} \mathrm{C}\right)$ における端子間抵抗は約 0.1 $\mathrm{m} \Omega$ であり，短絡時における室温から気化までの $I^{2} \mathrm{t}$ $\left(=\int \mathrm{i}^{2} \mathrm{~d} t\right)$ は䄪 $1 \times 10^{6} \mathrm{~A}^{2} \cdot s$ である。

<3，2>実験回路および実験方法図 3 は，図 2 の分岐回路 A点における短絡事故を模擬した，単相の実験 回路である。図において，N C L は主回路限流装置に適用 された $\mathrm{N}$ a 限流素子， $\mathrm{R} \mathrm{p}$ は並列抵抗， N F は短絡事故分 岐回路の配線用遮断器, そして $\mathrm{R}_{\mathrm{L}}$ は他の健全な分㞳回路 の負荷抵抗に相当している。N $\mathrm{R} \mathrm{p}$ の抵抗は $50 \mathrm{~m} \Omega$ である。記号を丸で囲ったものは電 王および電流の測定简所を示す。ノッチの電压 $\left(\mathrm{V}_{1}\right)$ は 計算 $\left(=\mathrm{V}_{\mathrm{N}}-\mathrm{V}_{2}\right)$ により求めた。回路は $3.3 \mathrm{k} \mathrm{V}$, $60 \mathrm{~Hz}$, 容量 $200.0 \mathrm{k} \mathrm{VAO} 3$ 相短絡発電機からなる 一次側電源, 投入/保護スイッチ, 短絡電流調整用のリア クトル, $3.3 \mathrm{k} \mathrm{V} / 330 \mathrm{~V}$ の単相短絡変圧器, および 定格電圧 $600 \mathrm{~V}$, 断面積 $400 \mathrm{~m} \mathrm{~m}^{2}$ のゴム絶縁電線 （往復線路長約 $6 \mathrm{~m}$ ) により構成されている。実験は変

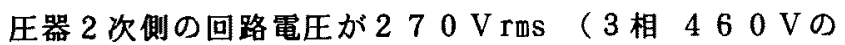
$1 / \sqrt{ } 3$ 相当) になるように短絡発電機の励磁電流を調整 して行なった。N C LとN F の部分をゴム絶縁電線で短䅂 したときの回路の短絡電流は，非対称波高值で $60 \mathrm{k} \mathrm{A}$, 力率は 0.125 であった。

つきに実験方法について述へる。スイッチSを閒じるこ とにより，短絡電流はNCLとN F を通じて流れ始める。 短絡電流はピークに達する前に，NCLが気化し限流動作 を行なうことにより，ある値以下に抑制される。この值は NFの遮断容量以下に設定されているので，NFは約 1 人 2 サイクルの遮断時間でこの短絡電流を遮断する。N F が 遮断すると，ひきつつき健全負荷群の角荷電流に相当する $\mathrm{I}_{\mathrm{RL}}$ がN C L， R p およびRL を通じて流れ続け，あらか じ設定された時間 $\mathrm{t} \mathrm{RL}$ 秒後にスイッチ $\mathrm{S} て ゙$ 遮断される。

実験は I RLと $\mathrm{t}_{\mathrm{RL}}$ をパラメータにして行った。I RLの大 きさは $R_{L}$ により， I RLの通電時間 $\mathrm{t}_{\mathrm{RL}}$ はスイッチ $\mathrm{S}$ の開 極により設定される。実回路での $I_{R L} や t_{R L}$ は, 短絡の継

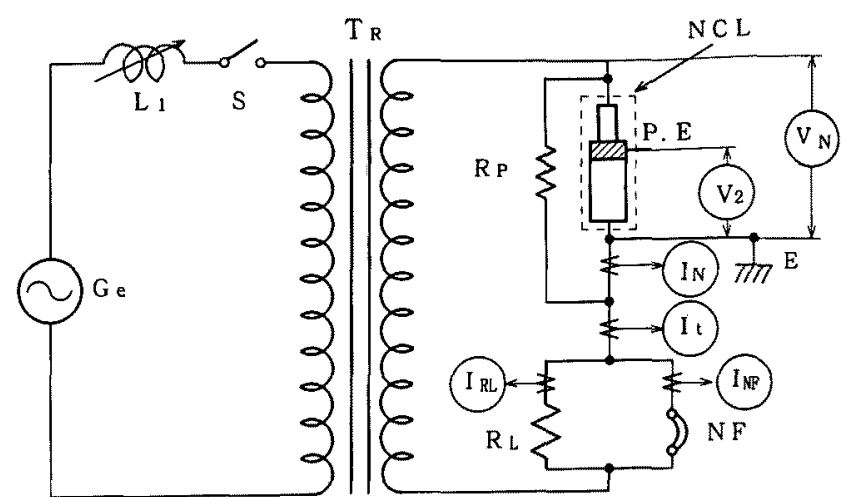

$\mathrm{Ge}$ : 短絡発電機 L：リアクトル $\mathrm{S}$ : 投入/保護スイッチ $\mathrm{T} \mathrm{R}$ ：変正器

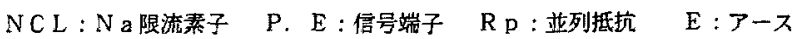
$R_{L}$ ：負荷抵抗 $N F ：$ 分岐回路配線用遮断器

図 3.実験回路

Fig. 3. Test circuit for the self-rehealing characteristic of the sodium limiter.

表 1，復旧実験での再通電電流 I RLとその通電特 間 $\mathrm{t}_{\mathrm{RL}}$

Table 1. Over load current and its duration af ter the fault in the experiment.

\begin{tabular}{|c|c|c|}
\hline ケース & $\mathrm{I}_{\mathrm{RL}}$ (A rms) & $\mathrm{t}_{\mathrm{RL}}(\mathrm{s})$ \\
\hline$(1)$ & 140 & 0.3 \\
\hline$(2)$ & 3520 & 0.3 \\
\hline$(3)$ & 4500 & 0.3 \\
\hline$(4)$ & 5340 & 0.3 \\
\hline$(5)$ & 6500 & 0.3 \\
\hline
\end{tabular}

( $t_{R L}$ は短絡開始時点からの時間)

続時間，電動機個々の回転速度の低下ならびに残留起電力 の大きさや位相に依存するので, その様相はかなり複雑で ある。ここでは I Rしおよび $\mathrm{t}_{\mathrm{R} L}$ は, 実测データと電気一機 械系計算プログラム「S C A P - M」による計算結果とか ら决定した [4]。

本実験に用いた I RL および $\mathrm{t}$ R L の組合せを表 Iに示す。 $\mathrm{t}_{\mathrm{R} L}$ としては，短䅂期間が短いため過渡電流の減衰も速 く最大 $0.15 \mathrm{~s}$ 程度を考えておけばよいが，0．15 s 以降の復旧状況も把握しておくために 0 ．3sに設定した。 I RLとしては $140 \mathrm{~A}$ から最大 $6500 \mathrm{~A}$ までの 5 ケース とした。ケース(1)は $140 \mathrm{~A}$ 極端に小さいが,これは再 通電電流がない場合とみなして復旧過程を調へるためであ る。またケースらの $6500 \mathrm{~A}$ は本実験に供したN C.Lの 定常状態における「電流－限流動作開始時間」の特性, いわゆる「 $\mathrm{I}-\mathrm{t}$ 特性」から $0.3 \mathrm{~s}$ まで流し得る最大 値として設定した。

く3.3>実験結果およびその考察 図 4 に、ケ一 ス(1) ( $\left.\mathrm{I}_{\mathrm{RL}}=140 \mathrm{~A}\right)$ およびケース(2) ( $\mathrm{I}_{\mathrm{RL}}=3520$ A（定常電流の 4.4 倍相当））の場合の実験のオシログ

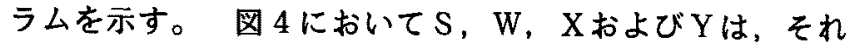
ぞれ短絡開始，N C L の限流動作開始，N F の遮断完了， 

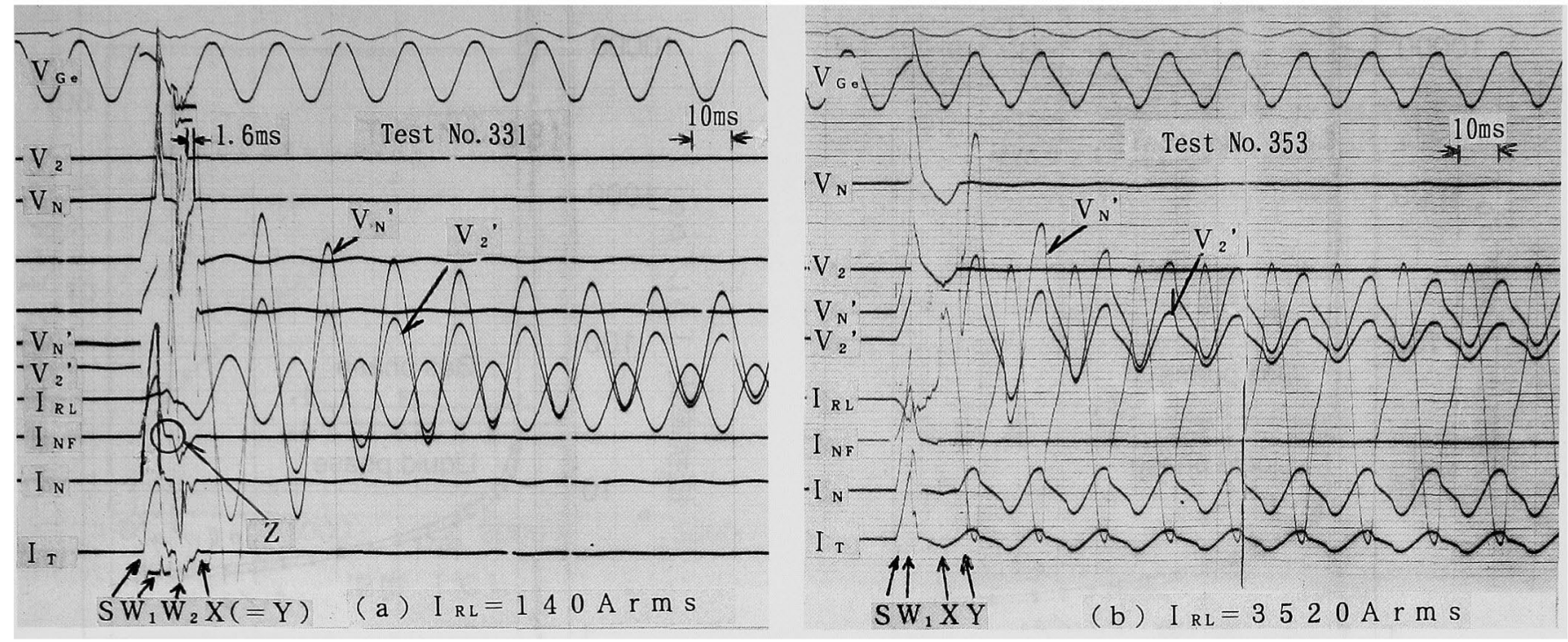

図 4、実験のオシログラム

Fig. 4. Typical test oscilograms in the experiment.

およびN C L の限流動作終了の時刻を表す。他の信号と区 別しやすくするため，I RLは逆極性とした。N C L の電圧

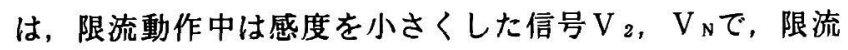
動作終了後の復旧過程は感度を高めた $\mathrm{V}_{2}{ }^{\prime}, \mathrm{V}_{\mathrm{N}}$ をを用いた。 なお,ケース(1)とケース(2)では I RLが大きく異なっている ため対応する信号の感度を変えているほか, $\mathrm{V}_{2}$ と $\mathrm{V}_{\mathrm{N}}$ の位 置も逆になっているので注意を要する。

まずケース(1)のオシログラム（a）について考察する。 S 点で投入/保護スイッチが閉じ，N C L およびN F を通 じて短絡電流が流れ始める。 W 1 点でN C L が気化（電圧 $\mathrm{V}_{2}, \mathrm{~V}_{\mathrm{N}}$ 等が発生) し抵抗が增大すると, 短絡電流は限流 され減少しはじめる（IN，I NF等が減少する）。ここで オシログラム（a）のZに示すように $I_{\mathrm{NF}}$ ２．０ｍ s 程 度の無通電の期間（ゼロポーズ）がある。これはN Fの接 点が限流される前の大きな短絡電流による電磁反発力で開 離し，慣性効果のためそのまま開離しており，N F を流れ ている電流が小さくなると一旦遮断されることによる。な おＩN にもゼロポースがあるように見えるが，I RLが小さ いため信号出力が小さいだけである。このときN C L は一 旦復旧している。

電流の減少とともに電磁反発力が小さくなり慣性効果屯 無くなってN F の接点が閉じると, 再び短絡電流がN C L とN F を通して流れ始める。 N C L は $W_{2}$ 点で再度気化し 限流動作を行う。 $W_{2}$ 点以降 X点までN C L は限流動作 と復旧動作を繰り返していることが $\mathrm{I} N, V_{\mathrm{N}}$ 等からわか る。

X点でN F は, 短絡電流を遮断する。その後 N C L と負 荷抵抗 $R_{L}$ にはひきつつき I RL $\left(\begin{array}{llll}1 & 4 & 0 & A\end{array}\right)$ が流れ続ける。 このケースでは I RLが小さいため, N C L は N F の遮断と 同時に限流動作を終了し（すなわち $\mathrm{Y}$ 点 $=\mathrm{X}$ 点），この 時点でN a は低抵抗状態に復旧している。以後 N C L の電 王 $\mathrm{V}_{2}{ }^{\prime}, \mathrm{V}_{\mathrm{N}}$ は時間の経過と共に減少しており， N C L の
抵抗は I RLを流しつつ低下していることがわかる。さら に興味あることは, $V_{\mathrm{N}}$ がX点で復旧しているのに対し， $\mathrm{V}_{2}$ はX点よりも約 $1.6 \mathrm{~m} \mathrm{~s}$ 早く復旧していることであ る。これは非ノッチ部がノッチ部よりも先に復旧している 事を示している。

以上の考察からケース(1)のように I RLが小さく再通電電 流がないものと見なせる場合には，N C L はN F の遮断完 了時点より先に非ノッチ部が復旧し， N F の遮断完了と同 時にノッチ部も復旧して限流動作を終了し，その後は負荷 電流 I RLを流しつつ抵抗が減衰していくことがわかる。

ケース(2)のオシログラム（b）では，N F はX点で短絡 電流を遮断している。しかし，N C L はX点以降む限流動 作を継続しており $\mathrm{Y}$ 点に至って復旧している。すなわち $\mathrm{X}$ 点から $Y$ 点の間では I RL は並列抵抗 $R p$ を通じて流れてお り，負荷への電力供給は $\mathrm{R} \mathrm{p}$ を通じて行われている。 $\mathrm{Y}$ 点 以後 N C L は I RLを流しつつ抵抗が減衰している。このケ 一スで, 非ノッチ部の復旧がノッチ部のそれよりも先行す

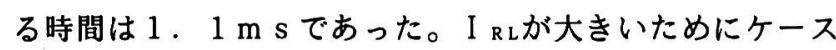
(1)と比へ非ノッチ部の復旧が遅くなっている。またこのケ ースでは, ケース(1)のゼロポーズのような期間は存在して いない。

図 5 は図 4 のオシログラムから，短絡開始時点（S点） を起点として, ナトリウム電路のノッチ部（l $l_{1}$ 部）およ び非ノッチ部( $l_{2}$ 部) における抵抗率 $\rho l_{1}, \rho l_{2}$ と常 温 $\left(25^{\circ} \mathrm{C}\right)$ におけるナトリウムの抵抗率 $\rho$ 。 ( 4.6 $\mu \Omega \cdot \mathrm{c} \mathrm{m})$ との比, すなわち抵抗率比 $\rho_{l_{1}} / \rho_{0}$ およよ゙ $\rho l_{2} / \rho$ 。を求めたものを示す。

短絡期間における N C L の抵抗は, 限流動作の開始直後 と終了直前は常温の 1 万倍を越える大きい值を示し，この 限流動作期間中では常温の約千倍から数千倍ときには 1 万 倍以上の間を複雑に変化している。この原因としては，限 流の開始直後と終了直前においては $N$ a は気体状態である 

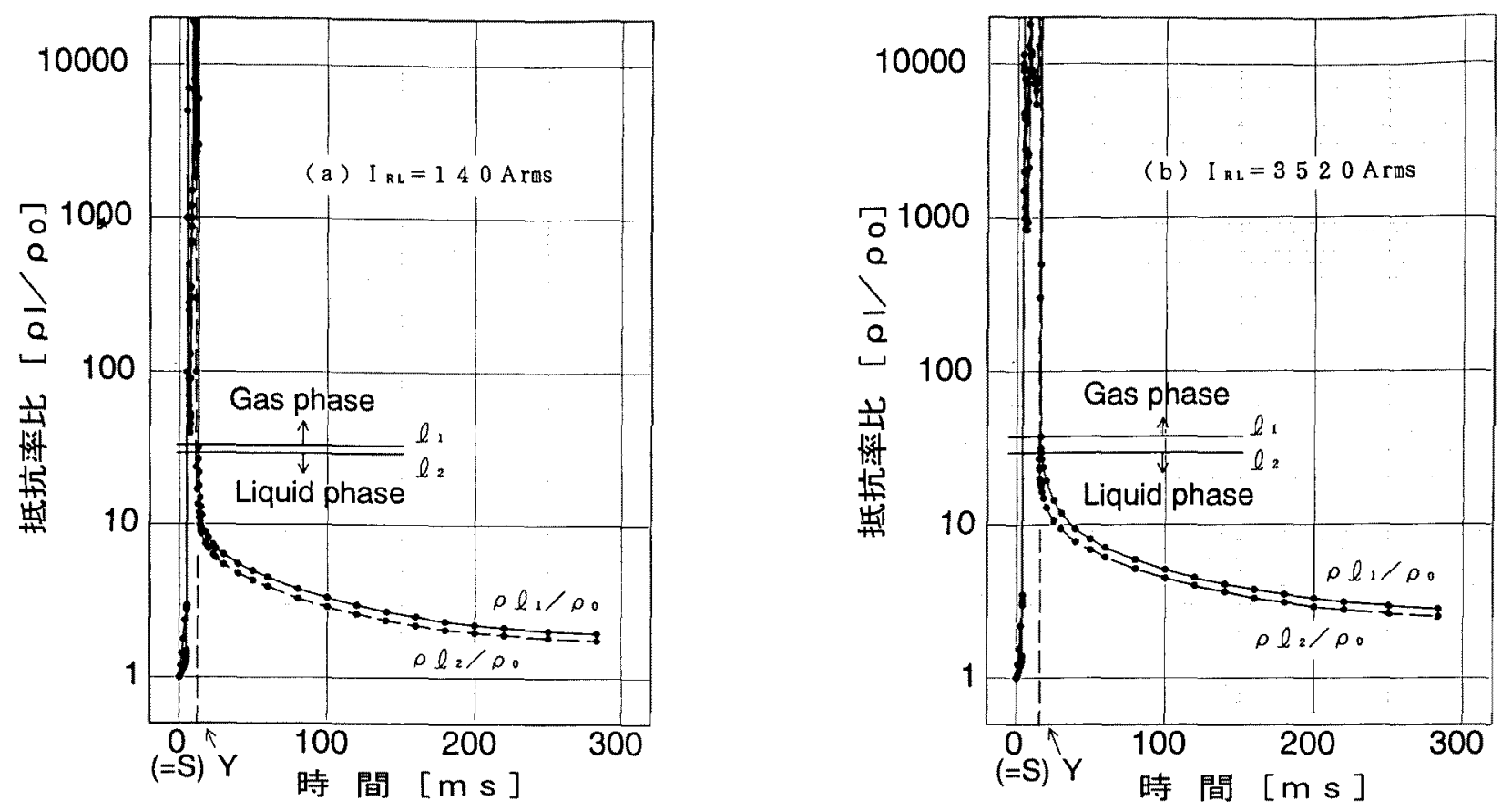

図 5. 抵抗率の比からみた $\mathrm{N}$ a限流素子の復旧特性

Fig.5. Relative electrical resistivity vs. timecharacteristics of the sodium limiter after current limiting operation.

が電離度が低く高抵抗になっているのに対し，限流動作期 間中においては注入エネルギーが多いため高電離プラズマ となり低抵抗になっているためであると考えられる。しか し両ケースの限流動作期間中における平均的な抵抗には差 がなかった。なお，熱力学的に数值計算されている $\mathrm{N}$ a 高温気体の抵抗から，限流期間中の $\mathrm{N}$ a の温度は数千度か ら数万度になっているものと推定される。

短絡電流が除去され限流動作が終了するY点で，ノッチ 部の抵抗は常温の約 $30 \sim 40$ 倍へ, 非ノッチ部の抵抗は 約 30 倍へとほぼ瞬時に低下し，以後時間の経過とともに 低下して行く。Y点から $100 \mathrm{~m} \mathrm{~s}$ の時点のノッチ部の抵 抗値は非ノッチ部のそれよりもケース(1)で約 $15 \%$ ，ケー ス(2)で的 $13 \%$ 高かった。またケース(1)のゼロポーズ期間 における素子の抵抗は，ノッチ部で常温の約 40 倍, 非ノ ッチ部で常温の約 50 倍であったが，電流が小さくまた計 測器の精度も悪く正確さは十分でない。

図 6 は，表1の全ケースについて限流動作終了時点（Y 点）を起点として，ノッチ部の抵抗率比 $\rho \ell_{1} / \rho 0$ をひ とつのグラフに示したものである。Y点ではいずれの抵抗 率比も $30 \sim 40$ となり I RL との相関は見られなかった。 $\mathrm{Y}$ 点以降ではいずれの場合も時間の経過としもに低下して いるが，IRLが大きくなるにしたがって低下のしかたが遅 く，復旧しにくくなることを示している。とくにケース (4)では限流動作完了後 $6.5 \mathrm{~m} \mathrm{~s}$ の時点で $1.7 \mathrm{~m} \mathrm{~s}$ 巾の $\mathrm{Na}$ の微小な気化が, ケース(5では $\mathrm{Y}$ 点以降 $80 \mathrm{~m} \mathrm{~s}$ まで に1.6〜3，2 m s 巾の 6 回の微小な気化が発生し, 抵 抗の低下が遅れた。さらにケース(5)では，200 は抵抗が减少しなかった。200 m 時点で素子の発熱と

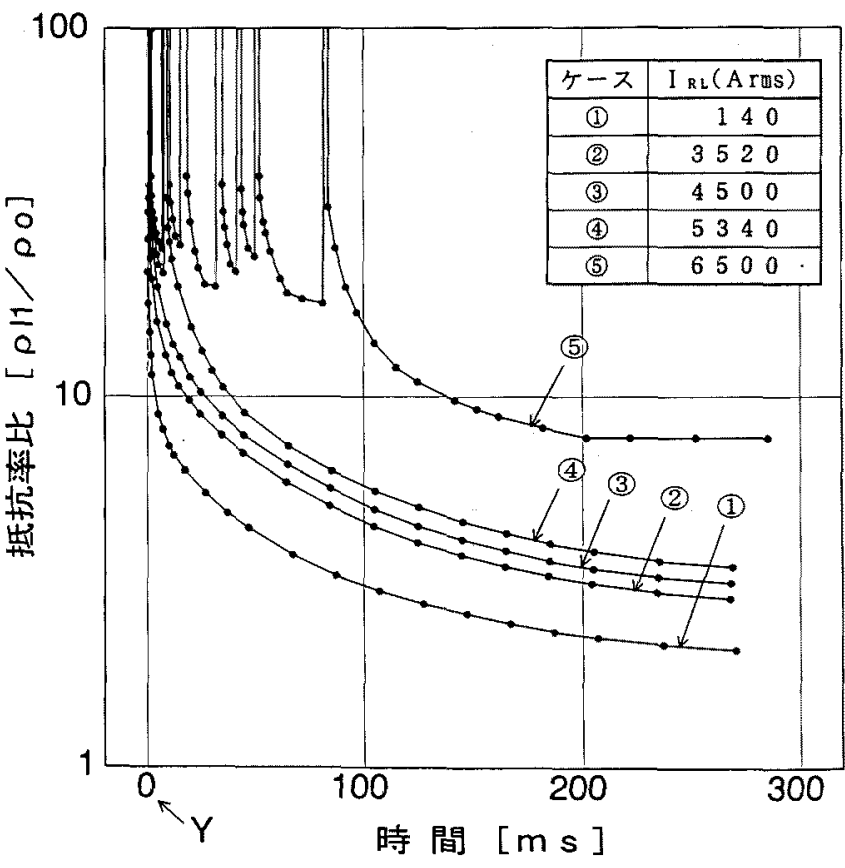

図 6. 限流動作完了後のノッチ部の復旧特性の $I_{R L}$ 依存性

Fig. 6. Infulence of $I_{R L}$ on the rehealing performance of constricted portion of the sodium element.

放熱が平衡状態になったものと推定される。また後述する 「 I $\mathrm{t}$ 特性」から $6500 \mathrm{~A}$ 通電時の素子の限流開始時 間は約 $0.3 \mathrm{~s}$ である。したがってケース(5)の場合このま ま継続して通電すれば素子は短時間のうちに再び限流動作 に到るものと推定される。 


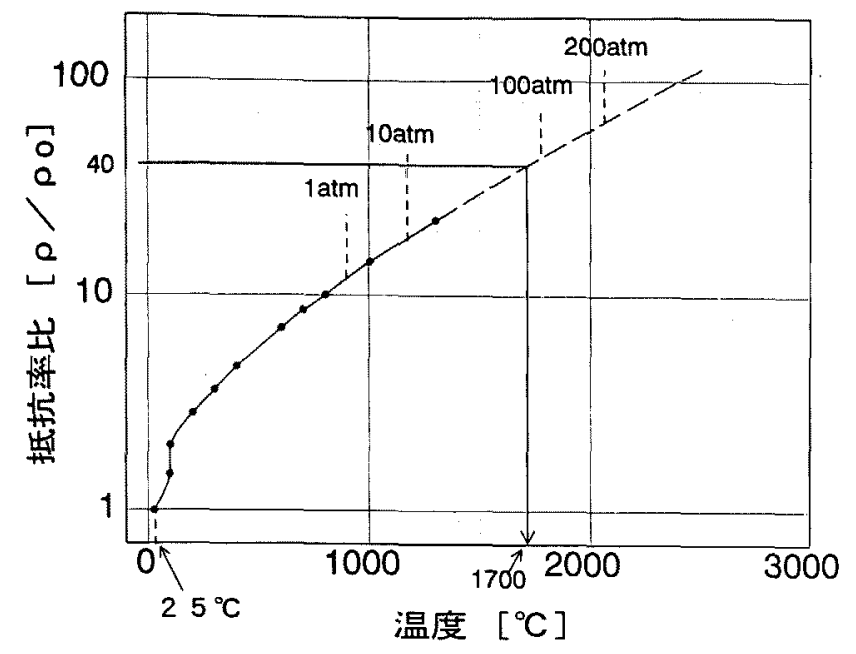

図 7. N a の温度一抵抗率比特性

Fig. 7. Relative electrical resistivity vs. temperature characteristic of sodium.

以上の結果から，NCLは限流動作をした後においても， ある值以下の過渡的な過電流に対して電流を流しつつ復旧 する機能を有していることが確認された。なお，表 1 の 5 つのケースにおけるNFの遮断時間は， $0.48 \sim 0.7$ 8 サイクル, 平均 0.67 サイクルで, 実際に用いられて いる製品と有意差はなかった。

ここで $\mathrm{Na}$ の抵抗が限流動作終了後の I RLの值に依存せ ずいずれの場合も常温の $30 \sim 40$ 倍となる物理的意味に ついて考察する。高压力下における $\mathrm{N}$ a の沸点付近の抵抗 率に関するテータは十分ではないが，図 7 に実線で示すよ うな1 $3000{ }^{\circ} \mathrm{C}$ までのテータ [5] の傾向を参考にすると, 飽和蒸気压下における液相の抵抗率曲線の延長による外挿 が妥当であると考える。図 7 から本実験における限流動作 終了時点のNCLの $\rho / \rho_{0}=30 \sim 40$ は, NCLの封 入ガス圧力である 100 a $\mathrm{t} \mathrm{m}\left(=1.01 \times 10^{7} \mathrm{P}\right.$ a $)$ 以下に対応している。このことからNCLの磁器円筒内の $\mathrm{Na}$ a，限流動作終了時点で気体から液体に相変化してい るものと推定される。またその時の液体 $\mathrm{N}$ aの温度は最高 $1700^{\circ} \mathrm{C}$ 程度と推定される。

\section{4. 主回路限流装異に適用する場合の過電流協調}

前節の実験結果をもとに，実験で用いたNCLを図 2 に 示す低左コントロールセンタの主回路限流装置に適用する 場合の過電流協調について検討する。

図 8 は過電流領域の協調を検討するための電流一時間 $(I-t)$ 特性図である。図8において曲線は室温におけ るNCLのI-t特性を，また矢印と丸印は実験において 得られたN C L の限流動作後の再通電特性を示す。一方 <3. 3>において述へたように，分岐短絡事故除去後の 健全負荷の過渡過電流の持続時間は最大で $0.15 \mathrm{~s}$ 程度 であり，しかも減衰して定常値になっていく。以上のこと

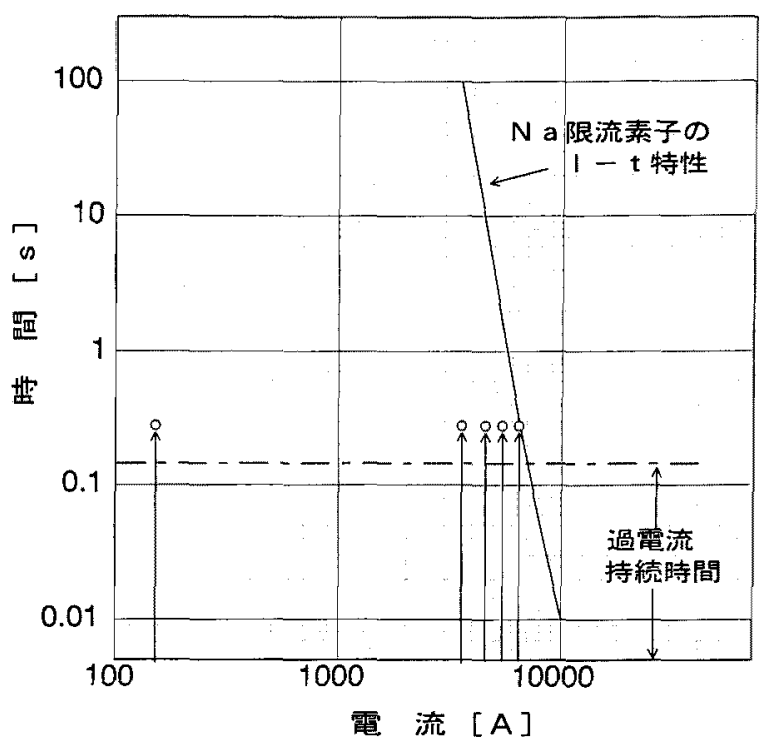

図 8,コントロールセンタの過電流協調の検討図

Fig. 8. Overcurrent coordination of the sodium limiter for a motor control center.

から結論されることは，図 2 に示すような回路に本 N C L を適用する場合においては，NCLは定常運転中に分岐回 路短絡事故が発生した場合でも短絡が除去されれば直ちに 再通電が可能で，再通電電流の「大きさ」×「通電時間」 の上限はNCLの定常状態の I - t 特性でほほ与えられる と考えてよい。これによりコントロールセンタの主回路に 設置したNCLと負荷側の電動機群との間の過電流協調が 検討でき，回路設計が可能になる。

\section{5.まとめ}

短絡事故の際，短絡電流を限流することによって機器 を保護する機能素子の一つとして，ナトリウム（N a ） をエレメントに用いた自己復旧型の限流素子がある。本論 文では， $\mathrm{N}$ a 限流素子と呼ぶこの素子について，限流動作 後の復旧過程を実験的に詳湅にあきらかにするとともに， この素子を低圧配電回路の一つであるコントロールセンタ の主回路に適用した埸合の過電流協調について検討を行っ た。結果をまとめると以下のようになる。

（1） $\mathrm{N}$ a 限流素子は，短絡電流が流れると $\mathrm{N}$ a が気化し， 常温の千倍程度から数千倍ときには一万倍以上へと抵抗が 急激に增加するとともに複雑に変化し，短絡電流を限流す る。短絡電流が遮断されると， $\mathrm{N}$ a は瞬間的に液体状態に 復旧し，素子の抵抗僢時に常温の30〜40 倍程度とな り以後漸次低下する。

（2） N a 限流素子に過負荷相当の電流を重畳して流す場 合においても，N a 限流素子は限流動作後（1）と同様に 復旧し，ひきつつきき電流を流し続けることが可能である。 この電流の「大きさ」メ「通電時間」の上限は, ほほ $\mathrm{N} \mathrm{a}$ 限流素子の定常状態における「電流一限流動作開始時間」 特性いわゆるI - $t$ 特性で与えられる。

（3）以上の実験結棵および考察から，低圧コントロール 
センタの主回路に $\mathrm{N}$ a 限流素子を適用する場合, $\mathrm{N}$ a 限流 素子と負荷の電動機群との過電流協調の検討ができ，最適 な回路設計が可能となった。

最後に本研究を進めるにあたりご指導を頂いた宮本紀男 教授（金沢工業大学, 当時三菱電機中央研究所主任研究員）, ならびに種々こ指導、ご助言を頂いた鬼頭幸生教授（名古 屋大学）に厚くお礼申し上げます。

(平成 5 年 7 月 12 日受付)

\section{文 献}

(1)T. Itoh, T.Miyamoto, Y. Wada, T. Mori \& H.Sasao : " Design Consideration on the P.P.F. for a Control Center " , IEEE Trans. Power Apparatus \& Systems, Vol. PAS-92, No. 4, pp1292 1297 (1973-8)

(2)Y. Nada, Y. Takagi, T.Mori, S. Hamano, T. Miyamoto \& T. Itoh : "Usefulness of PermanentPower Fuse in Control Centers with Molded Case Circuit Breakers ", IEEE Trans. Industry Appli-cations, Vol. IA-16, No. 1, pp30 38 (1980-1/2)

(3)和田, 浜野, 森, 宮本, 堀田 : 「自己復旧形限流素子 （永久ヒューズ）の自己復旧特性」電気学会開閉保護装 置研究会, SPD-76-4, (1976)

(4) 熊野・寺野・增井 : 「電気一機械系回路網解析プログ ラム」，昭49電気学会関西支部連大，G3-47

(5)A.N.Solov'ev : "Temperature Dependence of the Electrical Resistivity of Liquid Metals " High Temperature, pp165 166 (1969-9)
和田 勇一（正員）昭和 16 年 9 月 1 日生。 40 年静 岡大学工学部電気工学科卒業。同年 4 月三 菱電機(株)入社。以来, 中央研究所にて電 力用開閉機器, 限流装置などの研究開発に 従事。現在開閉機器研究開発グループのマ ネジャー。電気学会の受配電システム開閉 保護予防保全技術調查専門委員会委員長。 プラズマ・核融合学会およびI E E E 会員。

浜野 末信 (正員) 昭和 24 年 7 月 28 日生。 43 年 岡山県立笠岡工業高校卒業。同年 4 月三菱 電機(株)入社。中央研究所を経て平成 5 年 4 月から同社伊丹製作所に勤務。5 1 年大 阪府立工業短期大学卒業。入社以来, 電力 用開閏機器の研究開発に従事。現在ガス遮 断器の開発に従事。

森貞次郎 （正員）昭和 18 年 11 月 20 日生。 37 年兵庫県立尼崎工業高校卒業。同年 4 月三 菱電機(株)入社。以来, 中央研究所にて電 力用開閉機器, 限流装置などの研究開発に 従事。 